\title{
HIGH-TEMPERATURE GASIFICATION OF RDF WASTES AND MELTING OF FLY ASH OBTAINED FROM THE INCINERATION OF MUNICIPAL WASTES
}

\author{
Marián LÁzÁr, MÁria ČARnogurská*, Marta Lengyelová, JÁn Korba \\ Faculty of Mechanical Engineering, Technical University of Košice, Department of Power Engineering, \\ Vysokoškolská 4, 04200 Košice, the Slovak Republic \\ * corresponding author: maria.carnogurska@tuke.sk
}

ABSTRACT. This paper presents innovative solutions for thermal processing of selected components of municipal wastes (so-called RDF wastes) using a low-ionized dependent plasma arc generated by a progressive and promising plasma reactor technology. The application of this process can transform hazardous wastes into inert wastes while significantly reducing the overall volume of wastes. The experimental results presented in this paper show the outputs achieved with thermal disposal of RDF wastes and ash from municipal wastes.

KEYWORDS: plasma, gasification, waste, fly ash, vitrified slag.

\section{INTRODUCTION}

Currently, about $80 \%$ of the world's primary energy production relates directly or indirectly to the combustion of fossil energy carriers, such as coal, oil and natural gas [1, 16]. Combustion of these carriers releases the carbon in the structure of the energy source in the form of $\mathrm{CO}_{2}$. When thermal processes are applied, excessive production of $\mathrm{CO}_{2}$ from fossil fuel combustion increases the concentration of the gas product in the atmosphere. $\mathrm{CO}_{2}$ contributes significantly to global warming, to the increase in the average year-round temperature in the global context, and to changes in climatic conditions [2]. In recent research and development, priority is being given to new technologies that will be able to re-use the energy potential of various kinds of wastes produced by mankind [3].

Wastes, as such, often contain several valuable raw materials with a relatively high energy and material potential. Recovery of raw materials and energy from wastes is of significant economic and also environmental importance. The elimination of wastes that cannot be recycled by other processes is also of fundamental importance.

This paper investigates selected combustible components of municipal wastes (so-called RDF wastes), which are usually incinerated or deposited in a landfill. Energy recovery in the combustion process produces large amounts of unwanted by-products in the form of slag, fly ash and gaseous emissions [1, 8, 9]. Due to the environmental problems associated with incineration, we are looking for new ways of targeted recovery and disposal of municipal wastes. One way that has been investigated for disposing of wastes is to gasify them and melt them in a plasma reactor.

\section{STUDY AREA}

Technologies using thermal plasma offer a unique ability to transfer extremely high performance from a small volume of plasma to the charge being processed [15. The energy radiated from a source of thermal energy (a plasma column) and then transferred to batch particles decomposes the organic fraction of the waste, independently from the partial pressure of the oxygen. The part of the waste is reduced into simple gaseous compounds. Their presence in the synthesis gas is characterized by the composition of the batch and the boundary conditions of the gasification or of the high-temperature pyrolysis. Fig. 1 shows a block diagram representing the connection of the experimental laboratory plasma reactor that is used for laboratory investigations of the gasification and melting of wastes. A detailed description of the methodology for gasifying and melting the wastes is described in [1].

Decomposition of a heterogeneous batch of RDF at a temperature above $1000^{\circ} \mathrm{C}$, depending on the amount of available oxygen contained in the mixture, is characterized predominantly by the formation of certain components in the form of carbon monoxide, hydrogen and solid carbon [4]. Reducing the amount of untreated carbon in the system and increasing the amount in the synthesis gas in the form of $\mathrm{CO}$ can be achieved by introducing an oxidizing agent into the process. In order to increase the concentration of carbon monoxide and hydrogen in the synthesis gas, it is convenient to use oxidizing agents in the form of oxygen, carbon dioxide and, in some cases, water vapour [1. The oxidation reactions are in Table 1 .

The use of water vapour as an oxidizing agent provides an opportunity to increase the amount of hydrogen in the resulting mixture. However, the 


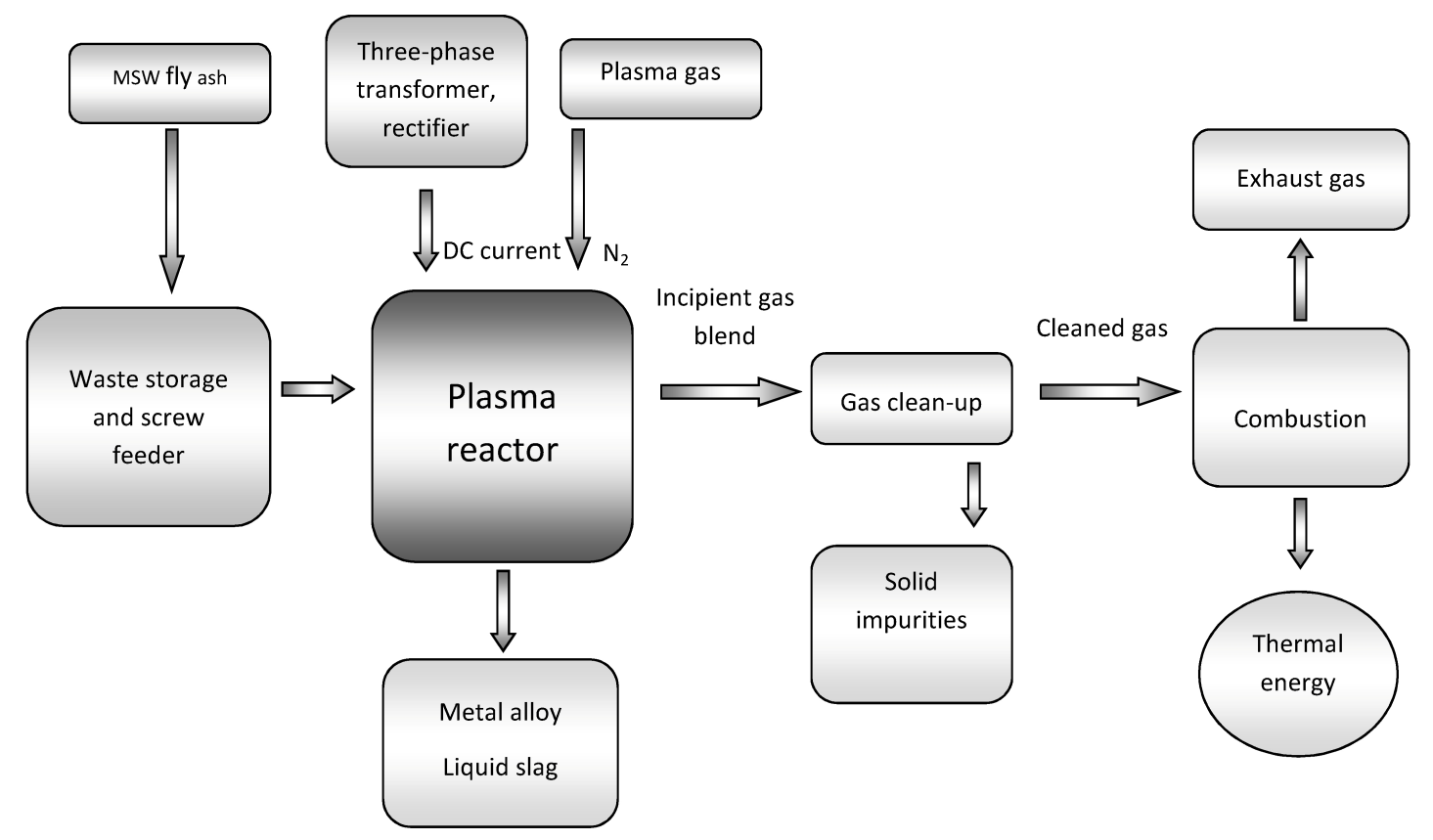

FiguRE 1. Block diagram representing the stages in the lab unit for gasifying and melting the wastes

\begin{tabular}{cc}
\hline Reaction & $\Delta H_{298}^{0}\left(10^{3} \mathrm{~J} \mathrm{~mol}^{-1}\right)$ \\
\hline $2 \mathrm{C}+\mathrm{O}_{2} \rightarrow 2 \mathrm{CO}$ & -221.0 \\
$\mathrm{C}+\mathrm{O}_{2} \rightarrow \mathrm{CO}_{2}$ & -393.5 \\
$\mathrm{C}+\mathrm{CO}_{2} \rightarrow 2 \mathrm{CO}$ & +172.0 \\
$\mathrm{C}+\mathrm{H}_{2} \mathrm{O} \rightarrow \mathrm{H}_{2}+\mathrm{CO}$ & +131.3 \\
$2 \mathrm{C}+2 \mathrm{H}_{2} \mathrm{O} \rightarrow 2 \mathrm{CO}+2 \mathrm{H}_{2}$ & +90.1 \\
\hline
\end{tabular}

TABLE 1. Oxidation reactions.

water gas reaction is endothermic. The endothermic reaction increases the specific energy consumption, based on the weight $(\mathrm{kg})$ of the processed batch. It is therefore necessary to optimize the ratio of $\mathrm{C} / \mathrm{O} / \mathrm{H}_{2} \mathrm{O}$ in the mixture, and to optimize the assessment of the energy and the economic profitability of the process.

\section{RAW MATERIALS USED FOR GASIFICATION AND THE PROPERTIES OF THE GAS}

For the purposes of the experimental tests on plasma processing of RDF wastes, we used a sample that was obtained by separating the combustible components of municipal wastes (Fig. 2). This mixture of selected components of municipal waste (plastic, paper, tetrapacks, dendromass, fabrics, etc.) was compacted after separation and stored in bales before it was dispatched for its final use.

The basic physical and chemical properties that characterized the batch (Fig. 2) were as follows: $37.93 \mathrm{wt} \%$ of $\mathrm{C}, 4.63 \mathrm{wt} \%$ of $\mathrm{H}, 5.72 \mathrm{wt} \%$ of $\mathrm{O}$, $12.33 \mathrm{wt} \%$ of $\mathrm{Cl}, 0.1 \mathrm{wt} \%$ of $\mathrm{S}, 0.05 \mathrm{wt} \%$ of $\mathrm{N}$, $26.34 \mathrm{wt} \%$ of ash and $24.90 \mathrm{wt} \%$ of moisture. The slag-forming oxides, which form the major part of the

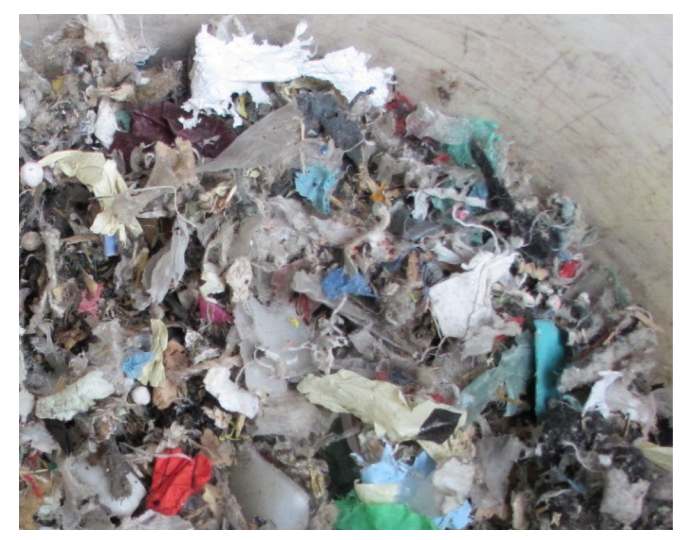

Figure 2. Sample of RDF wastes.

ash arising from RDF waste annealing of the samples at $815^{\circ} \mathrm{C}$, are represented in the flowing proportions: 17.1 wt $\%$ of $\mathrm{SiO}_{2} ; 48.63$ wt $\%$ of $\mathrm{CaO} ; 25.71$ wt\% of $\mathrm{Al}_{2} \mathrm{O}_{3} ; 2.48$ wt $\%$ of $\mathrm{MgO}$.

Given the high alkaline content of the calcium oxide in the ash, an acid flux is the most appropriate flux for reducing the melting point of the slag generated in the process of high-temperature gasification of the RDF waste. Silica flux was therefore used as a fluxing agent. The mixing ratio of the batch and the silica sand (96 wt $\%$ of $\mathrm{SiO}_{2}$ ) was set at $10: 1.1$ (RDF : flux). This ratio is based on theoretical considerations, on the changes in the composition of the melting point of the net batch and the batch with the addition of the flux. The changes in the composition can be determined on the basis of the ternary diagram of the dominant slag-forming oxides (Fig. 3a). Adding a flux in a defined ratio reduces the melting point of the emerging slag to approximately $1350^{\circ} \mathrm{C}$ (Fig. $\left.3 \mathrm{p}\right)$.

Energy recovery of waste materials with a high 

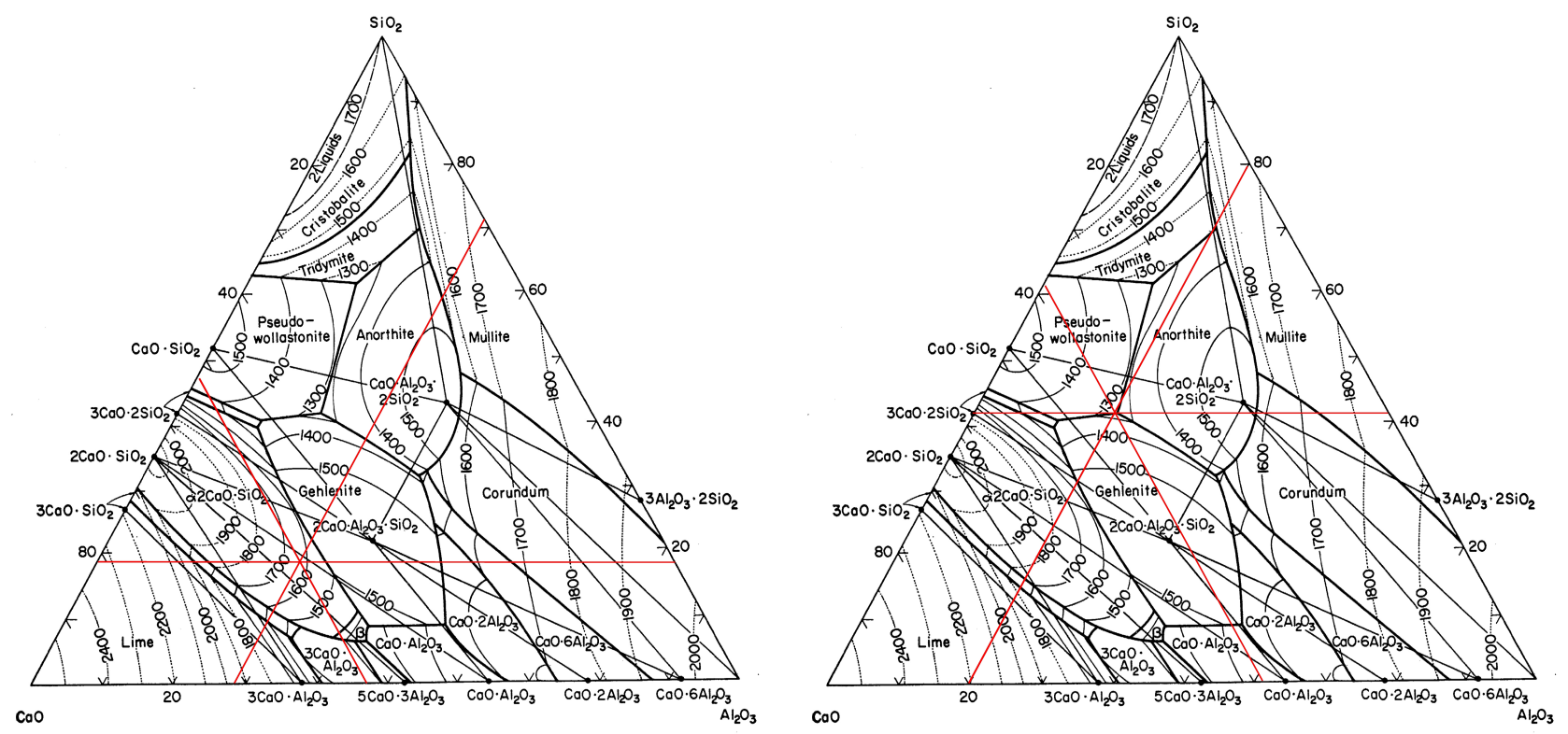

Figure 3. Ternary diagram $\mathrm{CaO}-\mathrm{SiO}_{2}-\mathrm{Al}_{2} \mathrm{O}_{3}$ for RDF wastes (a) and for RDF wastes + flux (b) [6].

\begin{tabular}{|c|c|c|c|}
\hline Operating parameters & & 1st stage & 2nd stage \\
\hline Gasification temperature & $\left({ }^{\circ} \mathrm{C}\right)$ & $1450-1500$ & $1450-1500$ \\
\hline Duration of experiment & $(\mathrm{s})$ & 1800 & 1200 \\
\hline Batch mass & $(\mathrm{kg})$ & 2.4 & 2.4 \\
\hline Dosage speed & $\left(10^{-3} \mathrm{~kg} \mathrm{~s}^{-1}\right)$ & 1.333 & 2 \\
\hline Plasma gas flow (nitrogen) & $\left(10^{-3} \mathrm{~m}^{3} \mathrm{~s}^{-1}\right)$ & 0.3133 & 0.1533 \\
\hline Oxygen flow & $\left(10^{-3} \mathrm{~m}^{3} \mathrm{~s}^{-1}\right)$ & 0.1333 & 0.1333 \\
\hline Production of synthesis gas based on kg batch* & $\left(\mathrm{m}^{3} \mathrm{~kg}^{-1}\right)$ & 1.35 & 1.803 \\
\hline
\end{tabular}

TABLE 2. Basic operating parameters for high-temperature gasification of RDF wastes.

content of flammable matter further requires a highly efficient batch decomposition process, while ensuring maximum possible production of combustible gaseous components such as $\mathrm{CO}$ and $\mathrm{H}_{2}$ [5]. Based on the given ratio of carbon and oxygen in the mixture of $3.158: 1.741$ (molar ratio), the theoretical total partial oxidation of the carbon atoms will be achieved by bringing a volume of oxygen corresponding to 1.417 mole per $100 \mathrm{~g}$ of the batch. This indicates that the process of gasification requires the additions of an oxidizer. The volume of oxidant from an external source in the form of pure oxygen is determined by calculation, taking into account results from previous experiments, with a flow rate of $0.133 \cdot 10^{-3} \mathrm{~m}^{3} \mathrm{~s}^{-1}$.

\section{EXPERIMENT}

High-temperature gasification of RDF wastes was examined at $30 \mathrm{kVA}$ on a plasma reactor with a dependent arc. A block diagram is shown in Fig. 1. The gasification process was carried out in the temperature range between 1450 and $1500^{\circ} \mathrm{C}$, for two different times of the experiment (two stages), at different speeds and with a different plasma gas flow. The basic parameters describing the gasification process and the amount of synthesis gas that was produced per $1 \mathrm{~kg}$ of the batch are summarized Table 2

In the first stage of batch gasification a sample of the syngas was taken. Its composition was as follows: $0.82 \mathrm{vol} \%$ of $\mathrm{CH}_{4}, 39.2 \mathrm{vol} \%$ of $\mathrm{H}_{2}, 0.04 \mathrm{vol} \%$ of $\mathrm{O}_{2}$, $17.4 \mathrm{vol} \%$ of $\mathrm{N}_{2}, 3.3 \mathrm{vol} \%$ of $\mathrm{CO}_{2}$, and $39.1 \mathrm{vol} \%$ of CO. In the next hour, the plasma reaction chamber of the plasma reactor was tempered to a temperature of about $1400^{\circ} \mathrm{C}$. During this time, it can be expected that the batch in the reservoir will dry up. The dosage batch restarted at a temperature of about $1447^{\circ} \mathrm{C}$. The ratio of the six most dominant gaseous components was as follows: $0.26 \mathrm{vol} \%$ of $\mathrm{CH}_{4}$, $50.9 \mathrm{vol} \%$ of $\mathrm{H}_{2}, 0.03 \mathrm{vol} \%$ of $\mathrm{O}_{2}, 25.4 \mathrm{vol} \%$ of $\mathrm{N}_{2}$, $1.1 \mathrm{vol} \%$ of $\mathrm{CO}_{2}$, and $43.5 \mathrm{vol} \%$ of $\mathrm{CO}$. The presence of chlorine, sulfur, heavy metals and other elements that are used in plastics as flame retardants (e.g., bromine) were not analyzed during gasification of the RDF wastes and therefore they do not form a part of the discussion in this paper.

High percentages of the two most dominant flammable components of the synthesis gas (i.e., $\mathrm{H}_{2}$ and $\mathrm{CO}$ ), which represent $78-94 \mathrm{vol} \%$ of the total composition of the synthesis gas, indicate its potential energy utilization. The high ratio of $\mathrm{H}_{2}$ and $\mathrm{CO}$ 


\begin{tabular}{lccccccc}
\hline \multicolumn{1}{c}{ Compound } & $\begin{array}{c}\text { RDF } \\
\text { Poland }\end{array}$ & $\begin{array}{c}\text { RDF } \\
\text { Poland }\end{array}$ & MSW & MSW & MSW & $\begin{array}{c}\text { RDF } \\
\text { Ostrava }\end{array}$ & $\begin{array}{c}\text { RDF } \\
\text { Ostrava }\end{array}$ \\
\hline Methane & 0.01 & 0.16 & 8.59 & 4.77 & 2.54 & 1.84 & 0.72 \\
Hydrogen & 16.3 & 31.6 & 44.5 & 48.9 & 30.3 & 45.6 & 36.74 \\
Oxygen & 0.07 & 0.02 & 0.16 & 0.11 & 0.74 & 0.65 & 0 \\
Nitrogen & 10.6 & 8.63 & 6.03 & 6.61 & 15.9 & 17.2 & 18.26 \\
$\mathrm{CO}_{2}$ & 28.9 & 11.3 & 6.6 & 1.66 & 2.42 & 1.46 & 1.56 \\
$\mathrm{CO}$ & 44.1 & 48.3 & 32.5 & 37.1 & 47.3 & 32.9 & 42.62 \\
Ethylene $\left(\mathrm{C}_{2} \mathrm{H}_{4}\right)$ & 0.001 & 0.004 & 0.97 & 0.49 & 0.52 & 0.27 & 0.08 \\
Ethan $\left(\mathrm{C}_{2} \mathrm{H}_{6}\right)$ & 0.001 & 0.001 & 0.055 & 0.031 & 0.023 & 0.013 & 0.002 \\
Ethyne $\left(\mathrm{C}_{2} \mathrm{H}_{2}\right)$ & 0.001 & 0.002 & 0.42 & 0.24 & 0.15 & 0.044 & 0.017 \\
Amount of $\mathrm{C}_{3}$ hydrocarbons & 0.01 & 0.01 & 0.011 & 0.004 & 0.004 & 0 & 0 \\
Amount of $\mathrm{C}_{4}$ hydrocarbons & 0.005 & 0.005 & 0.0099 & 0.004 & 0.005 & 0 & 0 \\
Amount of $\mathrm{C}_{5}-\mathrm{C}_{8}$ hydrocarbons & 0.005 & 0.005 & 0.17 & 0.12 & 0.09 & 0.0026 & 0.006 \\
\hline Heating capacity $\left(\mathrm{MJ} \mathrm{m}^{-3}\right)$ & 7.35 & 9.59 & 13.12 & 12.31 & 10.71 & 9.93 & - \\
\hline Estimated volume & & & & & & & 1.403 \\
\hline \multicolumn{1}{c}{ production $\left(\mathrm{m}^{3} \mathrm{~kg}^{-1}\right)$} & 1.065 & 1.453 & 1.069 & 0.973 & 0.404 & 1.324 \\
\hline
\end{tabular}

TABLE 3. The composition (in vol\%) of the synthesis gas obtained by gasification of RDF wastes and municipal solid wastes (MSW).

in the gas mixture that was produced was also demonstrated in experiments similar to high-temperature gasification of batches with a substantial proportion of combustibles (Table 3). Recovery of the synthesis gas, however, must be preceded by a purification process in which impurities are removed from the gas in the form of particulate matter (PM), and also sulfur and chlorine compounds.

Melting and gasification of wastes with a substantial proportion organic fraction in the plasma reactor produces not only the synthesis gas (which can be used for producing electricity and heat), but also a separate liquid oxidic phase (slag) and also flue dust [6, 11]. The slag produced in the process is a gasification product. Its composition can be modified by adding fluxes, so that the product can be used e.g. in construction. This means that the plasma melting process and gasification of wastes, depending on the type of waste that is treated, is a technology that meets all the requirements for a so-called BAT technology. This technology enables an assessment of the material and energy content of various types of wastes.

The second kind of material that we investigated was fly ash from the incineration of municipal wastes (without separating the unburned part). This type of waste belongs to the category of so-called hazardous wastes. It contains a high concentration of undesirable metals $(\mathrm{Hg}, \mathrm{Cd}, \mathrm{Pb}, \mathrm{Zn}, \mathrm{As}, \mathrm{Sb}, \mathrm{Sn}, \mathrm{Cu}$, $\mathrm{Ni}, \mathrm{Cr}, \mathrm{V}$ and $\mathrm{Ba}$ and their soluble salts), persistent organic substances, dioxins and furans. For this reason according to Paragraph 21, Section 8 of Act number $223 / 2001$ on the fly ash produced by the incineration of municipal wastes, the ash must be stabilized before it is finally disposed of 1 .

So-called "cementing" has become a relatively widespread technique for stabilizing fly ash. The fly ash is mixed with additives and with liquid reagents, and after the mixture hardens, the pollutants are fixed in the silicate matrix that has formed. The objective of the fly ash stabilization method is to ensure safer storage of the fly ash in landfills with a controlled regime.

A new, very promising way of environmentally friendly disposal of this hazardous waste, with subsequent use of final product, is vitrification in the plasma reactor $[7,8,11,13,14]$. During the vitrification process, the fly ash is melted together with the flux material at high temperature so as to create an oxidic glassy slag melt. This melt is then granulated or cast into moulds. The glassy nature of this product and its structure prevents leaching of toxic elements and their compounds that are trapped within (Table 4). Oxidic fly ash resulting from the process and consisting essentially of metals with a low boiling point $(\mathrm{Hg}, \mathrm{Cd}, \mathrm{Zn}, \mathrm{Pb}$ and the like.), mechanical fly ash, alkali metal (Na, K) and chlorides of metals, is collected in the cleaning circuit of the synthesis gas. This fly ash could have suitable properties for further metallurgical processing [7].

Tests of fly ash vitrification, a product of energy recovery from municipal wastes in incinerators, have proved that the plasma reactor technology is suitable for recovering and disposing of wastes of this type, both from the point of view of the technological process and from the point of view of the environment. The melting experiments showed the inert character of the oxidic vitrified slag that was produced ( $\mathrm{Ta}$ ble 4). The volume reduction of the processed batch is between $45-65 \%$. In addition, it is expected that the vitrified glass can be recovered. 


\begin{tabular}{|c|c|c|c|c|c|c|c|}
\hline \multirow[t]{4}{*}{ Measured value } & \multicolumn{4}{|c|}{ Aqueous extract } & \multicolumn{3}{|c|}{ Landfill Class } \\
\hline & \multirow{3}{*}{$\begin{array}{l}\text { Sample } \\
\text { fly ash } 1\end{array}$} & \multirow{3}{*}{$\begin{array}{c}\text { Sample } \\
\text { vitrified } \\
\text { slag } 1\end{array}$} & \multirow{3}{*}{$\begin{array}{c}\text { Sample } \\
\text { fly ash } 2\end{array}$} & \multirow{3}{*}{$\begin{array}{c}\text { Sample } \\
\text { vitrified } \\
\text { slag } 2\end{array}$} & SKIO* $^{*}$ & SKNNO* & SKNO* \\
\hline & & & & & \multicolumn{3}{|c|}{ Leachability class } \\
\hline & & & & & I. & II. & III. \\
\hline $\mathrm{pH}$ & - & 6.53 & 12.8 & 6.5 & $6-12$ & $5.5-13$ & $4-13.5$ \\
\hline Arsenic (As) & 0.013 & $<0.001$ & $<0.001$ & $<0.001$ & 0.05 & 0.2 & 2.5 \\
\hline Barium (Ba) & 4.721 & 0.018 & 0.345 & 0.012 & 2 & 10 & 30 \\
\hline Cadmium (Cd) & $<0.01$ & $<0.0003$ & $<0.0003$ & $<0.002$ & 0.004 & 0.1 & 0.5 \\
\hline Total Chrome (Cr) & 5.51 & 0.003 & 0.318 & 0.002 & 0.05 & 1 & 7 \\
\hline Cooper $(\mathrm{Cu})$ & 0.861 & 0.019 & 0.006 & 0.012 & 0.2 & 5 & 10 \\
\hline Mercury (Hg) & 69.6 & $<0.0001$ & 0.0002 & $<0.0001$ & 0.001 & 0.02 & 0.2 \\
\hline Molybdenum (Mo) & $<0.05$ & $<0.004$ & 0.234 & $<0.005$ & 0.05 & 1 & 3 \\
\hline Nickel (Ni) & 0.468 & $<0.002$ & $<0.002$ & $<0.01$ & 0.04 & 1 & 4 \\
\hline Lead $(\mathrm{Pb})$ & 8.612 & $<0.005$ & 0.6 & $<0.01$ & 0.05 & 1 & 5 \\
\hline Antimony (Sb) & 0.176 & $<0.001$ & $<0.001$ & $<0.001$ & 0.006 & 0.07 & 0.5 \\
\hline Selenium (Se) & 0.095 & $<0.001$ & $<0.001$ & $<0.001$ & 0.01 & 0.05 & 0.7 \\
\hline Zinc $(\mathrm{Zn})$ & 37.21 & 0.012 & 3.14 & 0.022 & 0.4 & 5 & 20 \\
\hline Chlorides & 37900 & $<1$ & 3404 & $<2$ & $80^{\dagger}$ & 1500 & 2500 \\
\hline Fluorides & 32.92 & $<0.1$ & 3.8 & 0.03 & 1 & 15 & 50 \\
\hline Sulfates & 12400 & $<2$ & 1255 & $<5$ & $100^{\dagger, \ddagger}$ & 2000 & 5000 \\
\hline Phenol index & - & $<0.03$ & $<0.01$ & $<0.002$ & 0.1 & 50 & 100 \\
\hline $\mathrm{CRL}^{*}$ & 103470 & 34 & 9852 & 38 & 400 & 6000 & 10000 \\
\hline Eco-toxicity & positive & negative & undetermined & negative & & & \\
\hline
\end{tabular}

TABLE 4. Results of the maceration test and norms for waste disposal (in $\mathrm{mgl}^{-1}$ ).

\section{Conclusion}

High temperature gasification tests have been carried out on sorted components of municipal wastes (RDF wastes) in order to investigate the possibility of recovering energy from them. If the results of this experiment are confirmed, it will be possible to move away from present-day waste management methods, such as landfilling. This pilot test has confirmed that it is possible to recover energy from the primary product - the synthesis gas - which is a by-product of plasma waste treatment. In addition, this technology offers effective reduction of the volume of RDF. The synthesis gas that is produced is rich in hydrogen and in carbon monoxide. After all undesirable ingredients have been removed, the gases can be used for energy production. The production of a gas mixture rich in hydrogen and carbon monoxide was confirmed for other samples with basic properties similar to the processed RDF wastes.

RDF waste gasification tests in a plasma reactor further confirmed that it is technologically possible to gasify the types of waste with high content of flammable matter. The solid products (glassy slag, alloys, flue dust) considered as by-products of gasification may also, depending on their composition, have some economic and social added value.
The technology presented in this paper could also handle certain types of hazardous wastes. Tests that have already been carried out involving melting the ash in a plasma reactor have shown that the plasma reactor technology, in cooperation with the equipment installed in WtE processes, e.g. incineration, provides an efficient way to dispose of the ash and to acquire an inert intermediate product in the form of a glassy slag. The economic justification for the process is dependent on the relation between the energy consumption for the process itself, the limiting conditions for batch processing, and the amount and the value of the products that can be recovered through the process (glassy vitrified slag, flue dust and synthesis gas). Anticipated future tightening of the limits on the content of pollutants in fly ashes sent for landfill, and also increasing costs for waste landfilling, indicate that the plasma melting process is a very promising new technology for dealing with RDF wastes.

\section{ACKNOWLEDGEMENTS}

This paper reports on work that has been supported by the Agency of the Ministry of Education of the Slovak Republic for the Structural Funds of the EU Operational Program "Research and Development" project ITMS 26220220044 , and by project VEGA 1/0004/14. 


\section{REFERENCES}

[1] Čarnogurská, M., Lázár, M. Plazmové spracovanie a zhodnocovanie odpadov. Košice: SjF TU Košice, 2013, $164 \mathrm{~s}$.

[2] Végsőová, O., Lukáč, P., Popčáková, D. Possibilities of energy utilization of selected types of woody species from the aspect of their influence on the environment. The Holistic Approach to Environment 2(1):23-28, 2012.

[3] Horbaj, P. Niekolko poznámok o základných parametroch, o určovaní súhrnného vzorca a o spalovaní tuhého komunálneho odpadu. Chemické listy 99(10):694-702, 2005.

[4] Lázár, M., Jasminská, N., Lengyelová, M. Experiment of gasification of the synthetically mixed sample of waste in nitrogen atmosphere. Acta mechanica et automatica 7(1):34-37, 2013, DOI: 10.2478/ama-2013-0006.

[5] Hrnčířová, M., Špiláček, M., Pospíšil, J. Size analysis of solid paritcles at the experimental device for multi-stage biomass combustion, Acta Polytechnica 54(1):22-27, 2014. doi:10.14311/AP.2014.54.0022

[6] Levin, E. M., Robbins, C. R., McMurdie, H.F. Phase Diagrams for Ceramists. Columbus, Ohio, 1969.

[7] Bokányi, L., et. al. High Value Added Fuel Production from Borsod Sub-bituminous Coal by Plasma Gasification and Catalytic Transformation. XVII. International Coal Preparation Congress Proceedings, Istanbul, 729-734, 2013.

[8] Michalec, Z., Taraba, B., Bojko, M., Kozubková, M.: CFD modeling of the low-temperature oxidation of coal. Archivum Combustionis 30(3), 133-144, 2010

[9] Nosek, R., Jandačka, J., Chabadová, J., Papučík, Š. Effect of fuel supply to heat power and formation of emissions in domestic boiler. Archivum Combustionis 30(4):347-352, 2010
[10] Lázár, M., Lengyelová, M., Imriš, I. Vitrifikácia popolčeka zo spalovania komunálneho odpadu v plazmovom reaktore. Chemické listy 108(2):148-155, 2014. 8

[11] Jasminská, N., et. al. Evaluation of hydrogen storage capacities on individual adsorbents. Measurement 56:219-230, 2014, DOI: 10.1016/j.measurement.2014.07.002. 9

[12] Qi, W., Shulei, T., Qunhui, W., Qifei, H., Jie, Y. Melting characteristics during the vitrification of MSWI fly ash with a pilot-scale diesel oil furnace. Journal of Hazardous Materials 160: 376-381, 2008, DOI: $10.1016 /$ j.jhazmat.2008.03.043

[13] Károly, Z., Mohai, I., Tóth, F., Wéber, F., Szépvölgyi, J. Production of glass-ceramics from fly ash using arc plasma. Journal of European Ceramic Society 27:17211725, 2007, DOI: 10.1016/j.jeurceramsoc.2006.05.015

[14] Zhao, P., Ni, Y., Jiang, L., Chen, L., Chen, M., Meng, Y. Destruction of inorganic municipal solid waste incinerator fly ash in a DC arc plasma furnace. Journal of Hazardous Material 181: 580-585, 2010, DOI: $10.1016 /$ j.jhazmat.2010.05.052

[15] Gomez, E., et. al. Thermal plasma technology for the treatment of waste: a critical review. Journal of Hazardous Materials 161: 614-626, 2009, DOI: 10.1016/j.jhazmat.2008.04.017

[16] Čarnogurská, M., Brestovič, T., Příhoda M. Modelling of Nitrogen Oxides Formation Applying Dimensional Analysis. Chemical and Process Engineering 32(3):175-184, 2011. DOI: 10.2478/v10176-011-0013-7. 